\title{
DAO Gene
}

National Cancer Institute

\section{Source}

National Cancer Institute. DAO Gene. NCI Thesaurus. Code C124940.

This gene is involved in the modification of amino acids. 